Anais da Academia Brasileira de Ciências (2012) 84(3): 759-766

(Annals of the Brazilian Academy of Sciences)

Printed version ISSN 0001-3765 / Online version ISSN 1678-2690

www.scielo.br/aabc

\title{
Seed size influence on germination responses to light and temperature of seven pioneer tree species from the Central Amazon
}

\author{
FABIANA F. AUD ${ }^{1}$ and ISOLDE D.K. FERRAZ ${ }^{2}$ \\ ${ }^{1}$ Instituto Nacional de Pesquisas da Amazônia (INPA), Coordenação de Pesquisa em Ecologia (CPEC), \\ Avenida André Araujo, 2936, Caixa Postal 47, Aleixo, 69087-000 Manaus, AM, Brasil \\ ${ }^{2}$ Instituto Nacional de Pesquisas da Amazônia (INPA), Coordenação de Pesquisa em Silvicultura Tropical (CPST), \\ Avenida André Araujo, 2936, Caixa Postal 47, Aleixo, 69087-000 Manaus, AM, Brasil \\ Manuscript received on September 10, 2010, accepted for publication on March 29, 2011
}

\begin{abstract}
In Amazon secondary forests are dominated by pioneer species that typically produce large amounts of small and dormant seeds that are able to form a persistent soil seed bank. Seed dormancy in this group of species is overcome by environmental conditions found in open areas, such as high irradiation or alternating temperatures. Nevertheless, a variety of germination responses to environmental factors is known among pioneers; some of them may germinate in diffuse light or in darkness condition at constant temperature. Seed mass can be considered as one of the factors that promotes this variety. Regarding species with very small seeds, it seems that the trigger for germination is light and for larger seeds temperature alternation may be a more important stimulus. In this study we established a relationship between seed mass and germination response to light and alternating temperature for a group of seven woody pioneer species from the Amazon forest. We found that an increase in seed mass was followed by a decrease in the need for light and an increase in the tolerance to alternating temperatures. Understanding germination strategies may contribute with the knowledge of species coexistence in high diverse environments and also may assist those involved in forest management and restoration.
\end{abstract}

Key words: Alternating temperatures, germinability, mean germination time, photoblastic germination, secondary forests, tropical trees.

\section{INTRODUCTION}

Large areas of primary tropical forests are currently being cleared to establish open areas for agriculture. In the Amazon region, many of these lands are abandoned after several years of use and often develop into secondary forests (Uhl et al. 1981, Uhl and Jordan 1984, Uhl 1987). Species composition of primary and secondary forests may vary according to the history of land use (Mesquita et al. 2001), intensity of anthropic perturbation

Correspondence to: Fabiana Ferraz Aud

E-mail: fabiana_aud@yahoo.com.br
(Buschbacher et al. 1988), competitive interactions among species (Huston 1979) and the availability of seeds in the soil seed bank (Dalling et al. 2002).

The formation of secondary forests is dominated by pioneer species (Guariguata and Ostertag 2001), which typically produce large amounts of small dormant seeds able to form a persistent soil seed bank (Swaine and Withmore 1988). Seed dormancy in this group of species is overcome by environmental conditions found in open areas, such as high irradiation with an increased proportion of red light (Vázquez-Yanes 1980, Vázquez-Yanes 
and Smith 1982, Orozco-Segovia and VázquezYanes 1989, Vázquez-Yanes et al. 1990), high or alternating temperatures (Vázquez-Yanes and Pérez-Garcia 1976, Vázquez-Yanes and OrozcoSegovia 1982) or any combination of these factors.

The need for light and alternating temperatures to germinate is interpreted as a way to recognize an opening in the canopy favorable to seedling growth because seeds with small nutrient supplies are not able to sustain development for long periods in the shade (Kennedy and Swaine 1992, Kyereh et al. 1999, Souza and Válio 2001). Nevertheless, some pioneer species can germinate in diffuse light under a dense canopy or in the dark and even at constant temperature (Kyereh et al. 1999, Pearson et al. 2002). Hence, photoblastism and dependency of temperature alternation are not characteristics shared by all pioneer species.

Indeed, a variety of germination responses to environmental factors is known among pioneer species (Brokaw 1987, Daws et al. 2002, Pearson et al. 2003). It is possible that this variety enhances the coexistence and maintenance of species diversity in this functional group. Studies of pioneer species natural regeneration have shown that both stochastic (chance and local history) and deterministic processes (competitive difference among species) can promote the coexistence of pioneer species (Dalling et al. 1998a, b, 2002, Dalling and Hubbel 2002).

Seed mass can be considered as one of the factors that promotes this variety. A relation between seed size and the effects of light intensity and quality on germination was found in herbaceous species from the temperate zone, where smaller seeds were more dependent on light for germination than larger ones (Milberg et al. 2000, Jankowska-Blaszczuk and Daws 2007). Seed size also affected germination requirements of arboreal pioneer species from a semi-deciduous tropical rain forest (Pearson et al. 2002, 2003). It seems that, for species with very small seeds $(<2 \mathrm{mg})$, the trigger for germination is light, as they need to photosynthesize soon due to limited internal resources. However, for larger seeds $(>2 \mathrm{mg})$, temperature alternation may be a more important stimulus due to the larger amount of internal resources the seedlings must have to reach the soil surface even when the seeds are buried in deeper soil layers (Pearson et al. 2002).

In this study we investigated whether the relationship between seed mass and germination response to light and temperature described by Pearson et al. (2002) can be confirmed for a group of seven woody pioneer species from "terra firme" (uplands) at the Amazon forest. We expected to find a relationship between seed mass and germination responses to light and temperature and assumed that with increasing seed mass the need for light would decrease and the tolerance to temperature alternations would increase. Understanding dispersal strategies, seed bank dynamics, germination, initial seedling establishment and development is fundamental to evaluate the relative importance of these processes in the coexistence of these species and to understand the initial stages of forest succession. Hence, this study may assist those involved in forest management and ecological restoration.

\section{MATERIALS AND METHODS}

Mature seeds were collected in secondary forests situated about $80 \mathrm{~km}$ north of the city of Manaus (Table I). The climate is tropical humid, classified as $A m$ according to the Köeppen scale. Annual rainfall varies between $1,900 \mathrm{~mm}$ and $2,300 \mathrm{~mm}$, with a dry season from June to October where monthly rainfall may fall below $100 \mathrm{~mm}$. The average annual temperature is $26{ }^{\circ} \mathrm{C}$, with diurnal temperature fluctuations between $19{ }^{\circ} \mathrm{C}$ and $39^{\circ} \mathrm{C}$ (Radambrasil 1978).

The arboreal pioneer species of this study are abundant in secondary forests in the Manaus region (Jones et al. 2005, Vizcarra 2006). The species were selected in order to encompass the largest possible variation in seed size and also to avoid dependence on 
phylogenetic traits. The average fresh mass of seeds smaller than $2 \mathrm{mg}$ was determined by weighing 10 replicates of 100 seeds each, and for seeds larger than $2 \mathrm{mg}, 100$ seeds were weighed individually (Table I).

Fruits of Bellucia grossularioides (L.) Triana, Byrsonima chrysophylla H.B. \& K. and Isertia hypoleuca Benth. were collected in six different secondary forests from three trees at least 60 meters apart. Fruits of Cecropia sciadophylla Mart., Croton lanjouwensis Jabl., Vismia cayennensis (Jacq.) Pers. and Jacaranda copaia (Aubl.) D.Don. were collected from one tree. After processing, the seeds were stored at $15^{\circ} \mathrm{C}$ for less than one month until the germination trials.

\section{GERMINATION TRIALS}

The germination trials were performed in incubators $\left(\right.$ LMS $^{\circledR}$ and FANEM $^{\circledR}$ (Mod. 347 CDG) under constant temperature at $25^{\circ} \mathrm{C}\left( \pm 2{ }^{\circ} \mathrm{C}\right)$ or alternating temperatures $(12 / 12 \mathrm{~h})$ at $20-30{ }^{\circ} \mathrm{C}$ or at $15-35{ }^{\circ} \mathrm{C}$, with a $12 \mathrm{~h}$ photoperiod (fluorescent light with about $70 \mu \mathrm{mol} \mathrm{m} \mathrm{m}^{-2} \mathrm{~s}^{-1}$ PAR) or in darkness. The period of highest temperature corresponded to the 12-hour light period. Cecropia sciadophylla and Vismia cayennensis seeds were placed on two layers of germination paper in $9 \mathrm{~cm}$ Petri dishes and moistened with $7 \mathrm{~mL}$ of distilled water. For Bellucia grossularioides, Croton lanjowensis, Isertia hypoleuca and Jacaranda copaia, transparent plastic boxes $(11 \times 11 \times 3.5 \mathrm{~cm})$ and $18 \mathrm{~mL}$ distilled water were used. Byrsonima chrysophylla seeds had the endocarp removed and due to the larger size were sown in moist vermiculite ( $37 \mathrm{~g}$ and $93 \mathrm{~mL}$ water) in plastic boxes $(17 \times 9 \times 4 \mathrm{~cm})$. All containers were maintained in loosely closed thin transparent plastic bags to avoid desiccation. Germination (root protrusion $\geq 5 \mathrm{~mm}$ with geotropic curvature) was assessed every day and the substrate was re-moistened if necessary. At the end of the observation period a cut test was performed on all ungerminated seeds to distinguish between dormant viable (hard seed) and dead seeds (mushy seed with fungi). Darkness was provided by wrapping the containers in two layers of aluminum foil. The germination in darkness condition was assessed only after the stabilization of the germination process under light conditions. Each treatment was replicated seven times, with 25 seeds of B. chrysophylla, C. lanjowensis and J. copaia, and with 50 seeds of the other species.

TABLE I

Seed fresh mass, fruiting pattern, seed dispersal, collection site and collection dates of seven woody pioneer species of the Central Amazon.

\begin{tabular}{|c|c|c|c|c|c|c|}
\hline Species & Family & $\begin{array}{l}\text { Seed mass } \\
(\mathrm{mg})\end{array}$ & $\begin{array}{c}\text { Frutification } \\
\text { pattern }\end{array}$ & Seed dispersal & Collection site & $\begin{array}{c}\text { Collection date } \\
\text { month/year }\end{array}$ \\
\hline Bellucia grossularioides (L.) Triana & Melastomataceae & $0.069 \pm 0.008$ & continuous $^{1}$ & zoochory & BR $174-\mathrm{km} 80^{3}$ & July/ 2007 \\
\hline Isertia hypoleuca Benth. & Rubia & $0.251 \pm 0.009$ & continuous $^{1}$ & 200 & BR $174-\mathrm{km} 80^{3}$ & July/ 2008 \\
\hline Vismia cayennensis (Jacq.) Pers. & Clusiaceae & $0.376 \pm 0.027$ & continuous $^{1}$ & zoochory & AM $010-{\mathrm{km} 08^{4}}^{2}$ & February/ 2008 \\
\hline Cecropia sciadophylla Mart. & Cecropiaceae & $1.086 \pm 0.054$ & annual $^{1}$ & zoochory & AM 010-km $08^{4}$ & February/ 2009 \\
\hline Jacaranda copaia (Aubl.) D.Don. & Bignoniaceae & $6.499 \pm 2.946$ & annual $^{2}$ & anemochory & BR $174-\mathrm{km} 60^{5}$ & March/ 2007 \\
\hline Croton lanjouwensis Jabl. & Euphorbiaceae & $14.187 \pm 3.618$ & supra-annual ${ }^{1}$ & autochory & BR 174-km $80^{3}$ & May/ 2006 \\
\hline Byrsonima chrysophylla H.B. \& K. & Malpigiaceae & $17.113 \pm 3.878$ & annual $^{1}$ & zoochory & BR $174-k m ~ 80^{3}$ & July/ 2007 \\
\hline
\end{tabular}

${ }^{1}$ Vizcarra (2006).

2 Jones et al. (2005).

${ }^{3}$ Reserves of Biological Dynamics of Forest Fragments Project (BDFFP) - INPA-SRI (02 $34^{\prime}$ S and $\left.60^{\circ} 07^{\prime} \mathrm{W}\right)$.

${ }^{4}$ São José Farm $\left(02^{\circ} 54^{\prime} 51^{\prime \prime}\right.$ S and 59 59'03” W).

${ }^{5}$ Tropical Silviculture Experimental Station - INPA $\left(02^{\circ} 47^{\prime} 5^{\prime \prime} \mathrm{S}\right.$ and $\left.60^{\circ} 11^{\prime} 51^{\prime \prime} \mathrm{W}\right)$. 


\section{DATA ANALYSIS}

Germination percentage and mean germination time affected by light and temperature were tested for significance using the Kruskal-Wallis test, and if the Kruskal-Wallis test indicated significance, the Wilcoxon test was applied for binary comparison, in both cases at 0.05 significance.

The relationship between seed mass and germination response to light and temperature stimuli was analyzed by a simple linear regression analysis between the Relative Light Germination (RLG) and the Relative Alternating Temperature Germination (RATG).

The RLG index expresses the light requirement for seed germination and was calculated according to Milberg et al. (2000) by dividing the germination percentage recorded in the light $(12 \mathrm{~h}$ light $/ 12 \mathrm{~h}$ dark cycle) by the sum of the germination percentages observed in light and in darkness. The values vary from 0 (germination only in darkness condition) to 1 (germination only in light).

Likewise, the RATG index expresses the requirement for alternating temperature and was calculated by dividing the percentage of germination under constant temperature $\left(25^{\circ} \mathrm{C}\right)$ by the sum of the germination percentages at constant temperature $\left(25^{\circ} \mathrm{C}\right)$ and alternating temperatures $\left(15-35^{\circ} \mathrm{C}\right.$ ). The values vary from 0 (germination only at alternating temperature) to 1 (germination only at constant temperature). All statistical analyses were carried out with the Systat v.10 software.

\section{RESULTS}

GERMINATION IN LIGHT AND IN DARKNESS CONDITION

The seeds of the seven pioneer species were all sensitive to light, as the germination percentages in the dark were never statistically higher than in light condition (Table II).

A simple linear regression between seed mass and Relative Light Germination (RLG) revealed a negative relationship $\left(\mathrm{R}^{2}=0.824, \mathrm{P}=0.005, \mathrm{y}=\right.$

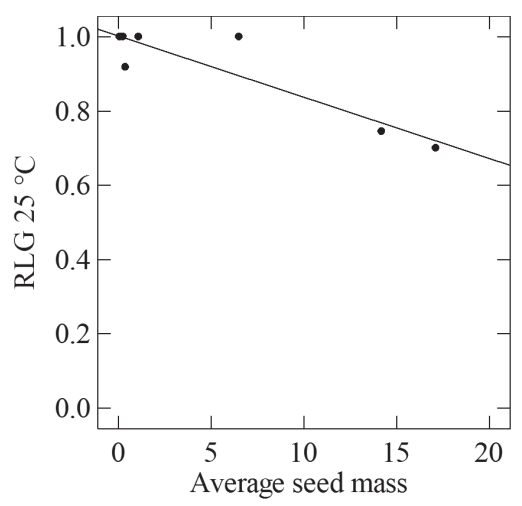

Figure 1 - Relationship between average fresh seed mass and Relative Light Germination (RLG) at $25^{\circ} \mathrm{C}$ of seven pioneer tree species from the Central Amazon. RLG: Germination percentage recorded in the light divided by the sum of germination percentages observed in the light and in darkness.

$-0.017 \mathrm{x}+1.002)$. With an increasing seed mass the need for light to germinate decreased (Fig. 1).

\section{GERMINATION AND TEMPERATURE}

A variety of responses was observed in relation to the temperature effects. Three species (Isertia hypoleuca, Cecropia sciadophylla and Jacaranda copaia) showed higher germinability at constant temperature. Even small daily alternating temperature reduced significantly germinability success in $I$. hypoleuca, $C$. sciadophylla and J. copaia. Two other species (Bellucia grossularioides and Vismia cayennensis) showed low germinability only when the daily temperature fluctuation was higher $\left(15-35^{\circ} \mathrm{C}\right)$. Croton lanjowensis germinated faster with small daily temperature fluctuations as indicated by mean germination time. Finally, the germination performance of Byrsonima crysophylla was improved (high germinability and low mean germination time) with both daily temperature alternations analyzed (Table II).

The linear regression between seed mass and RATG revealed a negative relationship $\left(\mathrm{R}^{2}=0.553\right.$, $\mathrm{P}=0.055, \mathrm{y}=-0.028 \mathrm{x}+0.945)$. Small seeds did not germinate under alternating temperatures, but the ability to germinate under diurnal alternation of temperature increased with increasing seed mass (Fig. 2). 
TABLE II

Germinability and mean germination time in light (12-hour photoperiod) and in darkness condition (mean \pm standard deviation) under three temperature conditions $\left(25^{\circ} \mathrm{C}\right.$ or $12-12 \mathrm{~h}$ alternating temperatures of $20-30{ }^{\circ} \mathrm{C}$ and $\left.15-35^{\circ} \mathrm{C}\right)$ of seven pioneer species ranked by fresh mass of seeds. Comparisons were done separately for each species, rows (lowercase letters) and columns (uppercase letters). Values followed by different letters are statistically different at $\mathbf{0 . 0 5}$ probability by the Wilcoxon test.

\begin{tabular}{|c|c|c|c|c|c|c|c|c|c|c|c|c|}
\hline \multirow{3}{*}{$\begin{array}{c}\begin{array}{c}\text { Species and mean } \\
\text { seed fresh mass (mg) }\end{array} \\
\\
\text { Bellucia } \\
\text { grossularioides }\end{array}$} & \multirow{3}{*}{$\begin{array}{c}\text { Temp. } \\
\left({ }^{\circ} \mathrm{C}\right)\end{array}$} & \multicolumn{8}{|c|}{ Germinability (\%) } & \multirow{2}{*}{\multicolumn{3}{|c|}{$\begin{array}{c}\text { Mean Germination } \\
\text { Time (days) } \\
\text { Light }\end{array}$}} \\
\hline & & \multicolumn{2}{|c|}{ Light } & \multicolumn{6}{|c|}{ Dark } & & & \\
\hline & & 88.6 & \pm 5.6 & A & $\mathrm{a}$ & 0.0 & \pm 0.0 & A & b & 30.1 & \pm 1.7 & A \\
\hline \multirow[t]{2}{*}{0.1} & $20-30$ & 84.6 & \pm 8.8 & A & $\mathrm{a}$ & 0.0 & \pm 0.0 & $\mathrm{~A}$ & $\mathrm{~b}$ & 39.8 & \pm 1.5 & B \\
\hline & $15-35$ & 1.1 & \pm 0.3 & B & $\mathrm{a}$ & 0.0 & \pm 0.0 & A & $\mathrm{a}$ & 53.7 & \pm 10.1 & $\mathrm{AB}$ \\
\hline Isertia hypoleuca & 25 & 52.9 & \pm 6.1 & A & $\mathrm{a}$ & 0.0 & \pm 0.0 & $\mathrm{~A}$ & $\mathrm{~b}$ & 65.2 & \pm 1.3 & A \\
\hline \multirow[t]{2}{*}{0.3} & $20-30$ & 35.1 & \pm 8.2 & B & $\mathrm{a}$ & 0.0 & \pm 0.0 & A & $\mathrm{b}$ & 63.2 & \pm 3.8 & A \\
\hline & $15-35$ & 11.7 & \pm 3.9 & $\mathrm{C}$ & $\mathrm{a}$ & 0.0 & \pm 0.0 & $\mathrm{~A}$ & $\mathrm{~b}$ & 73.7 & \pm 6.4 & B \\
\hline Vismia cayennensis & 25 & 33.1 & \pm 9.4 & A & $\mathrm{a}$ & 2.9 & \pm 2.0 & A & $\mathrm{b}$ & 14.8 & \pm 1.9 & A \\
\hline \multirow[t]{2}{*}{0.4} & $20-30$ & 32.6 & \pm 8.3 & A & $\mathrm{a}$ & 3.7 & \pm 3.1 & A & $\mathrm{b}$ & 14.5 & \pm 2.0 & A \\
\hline & $15-35$ & 10.3 & \pm 2.9 & B & $\mathrm{a}$ & 0.0 & \pm 0.0 & $\mathrm{~B}$ & $\mathrm{~b}$ & 36 & \pm 2.0 & B \\
\hline Cecropia sciadophyla & 25 & 40.6 & \pm 9.6 & A & $\mathrm{a}$ & 0.0 & \pm 0.0 & A & $\mathrm{b}$ & 22.6 & \pm 2.7 & A \\
\hline \multirow[t]{2}{*}{1.1} & $20-30$ & 12.6 & \pm 6.5 & B & $\mathrm{a}$ & 0.0 & \pm 0.0 & A & $\mathrm{b}$ & 26.6 & \pm 3.8 & A \\
\hline & $15-35$ & 0.0 & \pm 0.0 & $\mathrm{C}$ & $\mathrm{a}$ & 0.0 & \pm 0.0 & A & $\mathrm{a}$ & -- & -- & \\
\hline Jacaranda copaia & 25 & 34.8 & \pm 6.4 & A & $\mathrm{a}$ & 0.0 & \pm 0.0 & $\mathrm{~A}$ & $\mathrm{~b}$ & 30.7 & \pm 7.1 & A \\
\hline \multirow[t]{2}{*}{6.5} & $20-30$ & 2.3 & \pm 3.1 & B & $\mathrm{a}$ & 2.3 & \pm 4.5 & $\mathrm{~A}$ & $\mathrm{a}$ & 40.8 & \pm 8.8 & A \\
\hline & $15-35$ & 4.0 & \pm 5.7 & B & $\mathrm{a}$ & 1.1 & \pm 2.0 & A & $\mathrm{a}$ & 34.1 & \pm 6.7 & A \\
\hline Croton lanjowensis & 25 & 10.3 & \pm 7.6 & $\mathrm{AB}$ & $\mathrm{a}$ & 2.9 & \pm 3.0 & A & $\mathrm{b}$ & 31.2 & \pm 6.4 & B \\
\hline \multirow[t]{2}{*}{14.2} & $20-30$ & 16.0 & \pm 11.3 & A & $\mathrm{a}$ & 7.4 & \pm 6.7 & A & $\mathrm{a}$ & 17.1 & \pm 2.9 & A \\
\hline & $15-35$ & 3.4 & \pm 3.6 & B & $\mathrm{a}$ & 6.3 & \pm 6.9 & A & $\mathrm{a}$ & 31.8 & \pm 9.1 & $\mathrm{AB}$ \\
\hline $\begin{array}{l}\text { Byrsonima } \\
\text { crysophyla }\end{array}$ & 25 & 8.6 & \pm 5.4 & B & $\mathrm{a}$ & 3.4 & \pm 3.6 & A & $\mathrm{a}$ & 15.7 & \pm 5.5 & B \\
\hline \multirow[t]{2}{*}{17.1} & $20-30$ & 24.6 & \pm 9.4 & A & $\mathrm{a}$ & 6.3 & \pm 5.6 & A & b & 11.0 & \pm 3.2 & A \\
\hline & $15-35$ & 29.1 & \pm 8.6 & A & $\mathrm{a}$ & 6.9 & \pm 2.0 & $\mathrm{~A}$ & $\mathrm{~b}$ & 10.0 & \pm 2.1 & $\mathrm{~A}$ \\
\hline
\end{tabular}

\section{DISCUSSION}

The pioneer tree species used in this study are among the most common in secondary forests in Manaus region (Mesquita et al. 2001, Vizcarra 2006). Despite these species' abundance, information on the seed germination in relation to light and temperature of most of these species is scant. In this study, all seven species depended on light for seed germination. This was known from earlier studies on Jacaranda copaia (Prado-Oliveira 2003) and other species in the Cecropia genus, such as C. sciadophylla
(Holthuijzen and Boerboom 1982), C. obtusifolia Bertol. (Vázquez-Yanes 1979) and C. insignis Liebm. (Pearson et al. 2002), whereas no information was available for the other species investigated here.

Loss of light dependence related to increasing seed mass has been demonstrated earlier for herbaceous temperate species in southern Sweden (54 species with seed mass of 0.03 to $22.2 \mathrm{mg}$; Milberg et al. 2000 ), in a deciduous forest in Poland (27 species with mass of 0.01 to $10 \mathrm{mg}$; Jankowska-Blaszczuk and Daws 2007) and for 


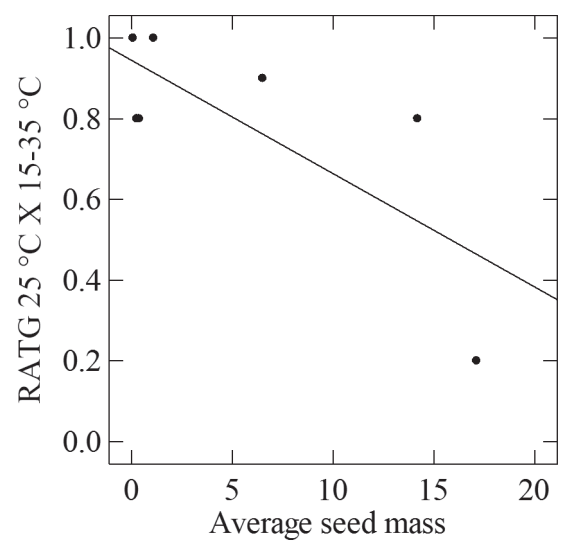

Figure 2 - Relationship between average seed fresh mass and Relative Alternating Temperature Germination (RATG) of seven pioneer tree species from the Central Amazon. RATG: percentage of germination under constant temperature $\left(25^{\circ} \mathrm{C}\right)$ divided by the sum of germination percentages at constant temperature $\left(25^{\circ} \mathrm{C}\right)$ and alternating temperatures $\left(12-12 \mathrm{~h} ; 15-35{ }^{\circ} \mathrm{C}\right)$.

pioneer tree species of a semideciduous tropical rainforest in Panama, where eight species with seed mass $<2$ mg were light sensitive, while larger seeds were not light dependant (nine species with mass from 0.04 to $88.30 \mathrm{mg}$; Pearson et al. 2002).

The seeds used in this study showed light dependence for germination with seed mass up to $17.1 \mathrm{mg}$. Based on the regression line, the seeds would lose light dependency $(\mathrm{RLG}=0.5)$ only at a mass of about $29.5 \mathrm{mg}$. However, this assumption should be taken with caution. Light response for germination is complex because differences in the photon fluence rate, spectral composition and also intrinsic factors such as the level of dormancy, which can change seasonally or during postdispersal treatments, cannot be excluded. Nevertheless, the results confirm that increasing seed's internal resources reduces the need for light stimulus for germination, supporting the idea of a general pattern in tropical and temperate zones.

Some pioneer tree seeds are sensitive to heat shock (Ochroma lagopus Sw.; (Vázquez-Yanes 1974), or alternating temperatures (Heliocarpus donnellsmithii Rose; (Vázquez-Yanes and Orozco-Segovia 1982), Solanum hayessi Fernald, Guazuma ulmifolia
Lam., Ochroma pyramidale (Cav. ex Lam.) Urb. and Ceiba pentandra (L.) Gaertn. (Pearson et al. 2002)). Germination cues by alternating temperatures are also common in grasses (Thompson and Grime 1983) and may be the most important factor in overcoming water impermeability of the seed coat (Baskin and Baskin 1998). None of the species in this study had waterimpermeable seed coats. In Byrsonima chrysophylla, the hard endocarps, which may have imposed physical dormancy, had been removed before the germination trials, supporting the view that the negative correlation between RATG and seed mass can be explained by increasing tolerance to alternating temperature with increasing seed mass. Small seeded tropical species with similar seed mass (from 0.04 to $0.15 \mathrm{mg}$ ) studied by Daws et al. (2002) as Piper dilatatum, P. hispidum, $P$. marginatum and $P$. peltatum, and by Pearson et al. (2002) as Piper peltatum, P. dilatatum and Cecropia insignis (from 0.04 to $0.68 \mathrm{mg}$ ) were also intolerant to temperature alternations.

Beneficial effects of alternating temperatures on germination rates of heavier seeds were shown by Pearson et al. (2002) for four species with seed mass of $2.4 \mathrm{mg}-70 \mathrm{mg}$ and in a subsequent study, of Solanum hayessi (2.4 mg; Pearson et al. 2003). Based on the linear regression of RATG in this study, only seeds with a mass $>15.9 \mathrm{mg}$ would perform better under alternating rather than constant temperature conditions (RATG $=0.5$ ). This result may not be directly comparable, as the RATG index was not used in the earlier studies cited here. However, the pattern is similar since the germination of the Amazon pioneer tree species also showed an increasing tolerance or even a demand for daily temperature alternation with increasing seed mass.

Unlike light, diurnal temperature fluctuations in open areas can reach several centimeters into the soil (Raich and Gong 1990). In this sense, temperature could be a more important germination trigger than light for larger seeds (Pearson et al. 2002). Species with very small seeds and very limited resources can only emerge close to the 
surface in partly protected areas under fairly constant temperature conditions. These species would be restricted to small gaps, forest borders and places with advanced regeneration. Larger seeded species could occupy open areas with pronounced diurnal temperature alterations because the larger resources would permit the emergence from soil depths where light cannot penetrate.

Species composition in natural regeneration could be influenced by specific germination requirements of the species, and small variations in germination at micro sites might favor the coexistence of species from the same functional group.

In seven abundant pioneer tree species from secondary forests of the Central Amazon, a relationship was found between seed mass, sensitivity to light and tolerance to diurnal temperature alternations. The RLG index proposed by Milberg et al. (2000) and the newly defined RATG index were useful tools to detect small differences in the demands for light and temperature in this group of species. With increasing seed mass, germination may become possible in micro sites with larger diurnal temperature fluctuations and from deeper soil areas. Thus, a gradient of responses to germination cues exists in the functional group of pioneer tree species and consequently a gradient in the preferences to certain microsites. Such information, based on germination data collected in the laboratory, is important for forest management and reforestation of degraded areas as it enhances understanding and helps the prediction of natural regeneration.

\section{ACKNOWLEDGMENTS}

We would like to thank the financial support given to this work by Coordenação de Aperfeiçoamento de Pessoal de Nível Superior (CAPES); Projeto Manejo e Ecologia de Sementes Florestais da Amazônia Conselho Nacional de Desenvolvimento Científico e Tecnológico (CNPq); Biological Dynamics of Forest Fragments Project - Humid Tropical
Forest Ecosystem (BDFFP) - Instituto Nacional de Pesquisas da Amazônia (INPA) and the Smithsonian Institution. This is the study 567 of the technical series of BDFFP.

\section{RESUMO}

Na Amazônia as florestas secundárias são dominadas por espécies pioneiras que, normalmente, produzem grandes quantidades de sementes pequenas, dormentes e capazes de formar bancos de sementes no solo. A dormência neste grupo de espécies é superada pelas condições ambientais de áreas abertas, como alta irradiação ou alternância de temperaturas. No entanto, uma variedade de respostas de germinação aos fatores ambientais é conhecida entre as pioneiras; algumas germinam em luz difusa ou no escuro sob temperatura constante. Um dos fatores promotores desta variedade é a massa das sementes. Parece que para as espécies com sementes muito pequenas, o estímulo para que ocorra germinação é a luz e, para sementes maiores, a alternância de temperatura pode ser um estímulo mais importante. Neste estudo, estabeleceu-se uma relação entre a massa das sementes e a resposta de germinação à luz e temperatura para sete espécies pioneiras arbóreas da floresta amazônica. Descobrimos que o aumento na massa da semente foi acompanhado por diminuição da necessidade por luz e aumento da tolerância à alternância de temperatura. Compreender estratégias de germinação pode contribuir para os conhecimentos sobre a coexistência de espécies em ambientes altamente diversos e também pode ajudar aos pesquisadores envolvidos no manejo e restauração florestal.

Palavras-chave: Alternância de temperatura, germinabilidade, tempo médio de germinação, germinação fotoblástica, florestas secundárias, árvores tropicais.

\section{REFERENCES}

BASKIN CC AND BASKIN JM. 1998. Seeds: Ecology, Biogeography and Evolution of Dormancy and Germination, New York: Academic Press, 666 p.

BROKAW NVL. 1987. Gap-phase regeneration of three pioneer tree species in a tropical forest. J Ecol 75: 9-19.

BUSCHBACHER R, UHL C AND SERRÃO EAS. 1988. Abandoned pastures in eastern Amazonia. II Nutrient stocks in the soil and vegetation. J Ecol 76: 682-699. 
DALling JW AND HubBEL SP. 2002. Seed size, growth rate and gap microsite conditions as determinants of recruitment success for pioneer species. J Ecol 90: 557-568.

DALling JW, HubBel SP AND Silveira K. 1998b. Seed dispersal, seedling establishment and gap partitioning among tropical pioneer trees. J Ecol 86: 674-689.

Dalling JW, Muller-LANDAu HC, Wright SJ AND HuBBell SP. 2002. Role of dispersal in the recruitment limitation of neotropical pioneer species. J Ecol 90: 714-727.

DALling JW, SWAINE MD AND GARWOOd NC. 1998a. Dispersal patterns and seed bank dynamics of pioneer trees in moist tropical forest. Ecology 79: 564-578.

Daws MI, Burslem DFRP, CRABTreE LM, KirkMan P, Mullins CE AND DALLING JW. 2002. Differences in seed germination responses may promote coexistence of four sympatric Piper species. Funct Ecol 16: 258-267.

GuARiguatA MR AND Ostertag R. 2001. Neotropical secondary forest succession: changes in structural and functional characteristics. Forest Ecol Manag 148: 185-206.

HolThUIJZEN AMA AND BoERBOOM JHA. 1982. The Cecropia seedbanks in the Surinam lowland rain forest. Biotropica 14: 62-68.

Huston M. 1979. A general hypothesis of species diversity. Amer Nat 113: 81-101.

JANKOWSKA-BLASZCZUK M AND DAWS MI. 2007. Impact of red:far red ratios on germination of temperate forest herbs in relation to shade tolerance, seed mass and persistence in the soil. Funct Ecol 21: 1055-1062.

Jones FA, Chen J, Weng GJ AND HubBell SP. 2005. A genetic evaluation of seed dispersal in the neotropical tree Jacaranda copaia (Bignoniaceae). The Amer Nat 166: 543-555.

KENNEDY DK AND SWAINE MD. 1992. Germination and growth of colonizing species in artificial gaps of different sizes in dipterocarp rain forest. Philos Trans R Soc London [Biol] 335: 357-367.

KyereH B, Swaine MD AND Thompson J. 1999. Effect of light on the germination of forest trees in Ghana. J Ecol 87: 772-783.

MEsquita RCG, ICKes K, GANAde G AND Williamson GB. 2001. Alternative successional pathways in the Amazon Basin. J Ecol 89: 528-537.

Milberg P, ANDERSSON L AND ThOMPson K. 2000. Large seeded species are less dependent on light for germination than small seeded ones. Seed Sci Res 10: 99-104.

OrozCo-SEgOVIA A AND VÁzQUEZ-YANES C. 1989. Light effect on seed germination in Piper L. Acta Oecol Plant 10: $125-146$.

PEARSON THR, BuRslem DFRP, Mullins CE AND DALLing JW. 2002. Germination Ecology of neotropical pioneers: Interacting effects of environmental conditions and seed size. Ecology 83: 2798-2807.

PEARson THR, BURslem DFRP, Mullins CE AND DALLING JW. 2003. Functional significance of photoblastic germination in neotropical pioneer trees: a seeds eye view. Funct Ecol 17: 394-402.
Prado-Oliveira MC. 2003. A longevidade e a perda da dormência de diásporos de espécies florestais tropicais em áreas com diferentes graus de alteração. Dissertation, Instituto Nacional de Pesquisas da Amazônia Universidade Federal do Amazonas. (Unpublished).

RADAMBRASIL - PROGRAMA DE INTEGRAÇÃo NACIONAL. 1978. Levantamento de Recursos Naturais vol. 18. Folha AS 20, Manaus, AM. Rio de Janeiro: Ministério de Minas e Energia - Departamento Nacional de Produção Mineral, 261 p.

RAICH JW AND GONG WK. 1990. Effects of canopy opening on tree seed germination in a Malaysian dipterocarp forest. J Trop Ecol 6: 203-217.

SoUZA RP AND VÁLIO IFM. 2001. Seed size, seed germination and seedling survival of brazilian tropical tree species differing in successional status. Biotropica 33: 447-457.

SWAINE MD AND WHITMORE TC. 1988. On the definition of ecological species groups in tropical rain forest. Vegetatio 75: 81-86.

THOMPSON K AND GRIME JP. 1983. A comparative study of germination responses to diurnally-fluctuating temperatures. J Appl Ecol 20: 141-156.

UHL C. 1987. Factors controlling succession following slash and burn agriculture in Amazonia. The J Ecol 75: 377-407.

Uhl C, Clark K, Clark H AND MuRPHY P. 1981. Early plant succession after cutting and burning in the upper Rio Negro Region of the Amazon Basin. The J Ecol 69: 631-649.

UHL C AND JORDAN CF. 1984. Succession and nutrient dynamics following forest cutting and burning in Amazonia. Ecology 65: 1476-1490.

VÁZQUEZ-YANES C. 1974. Studies on the germination of seeds of Ochroma lagopus Swartz. Turrialba 24: 176-179.

VÁZQUEZ-YANES C. 1979. Notas sobre la ecofisiologia de la germinacion de Cecropia obtusifolia Bertol. Turrialba 29: 147-149.

VÁZQUEZ-YANES C. 1980. Light quality and seed germination in Cecropia obtusifolia and Piper auritum from a tropical rainforest in Mexico. Phyton 38: 33-35.

VÁzQueZ-YANES C AND OROZCO-SEGOVIA A. 1982. Seed germination of a tropical rainforest tree Heliocarpus donnell-smithii in response to diurnal fluctuations of temperature. Physiol Plant 56: 295-298.

VÁZQUEZ-YANES C, OROZCO-SEGOVIA A, RINCÓN E, SANChEZ-Coronado ME, HuAnte R, TOLEdo JR AND BARRADAS UL. 1990. Light beneath the litter in a tropical rain forest: Effect on seed germination. Ecology 71: 1952-1958.

VÁZQUEZ-YANES C AND PÉREZ-GARCIA B. 1976. Notas sobre la morfologia y la anatomía de la testa de las semillas de Ochroma lagopus Sw. Turrialba 26: 310-311.

VÁZQUEZ-YANES C AND SMITH H. 1982. Phytochrome control of seed germination in the tropical rain forest pioneer trees, Cecropia obtusifolia and Piper auritum, and its ecological significance. New Phytol 92: 477-485.

VIZCARRA TB. 2006. Estratégias reprodutivas de espécies pioneiras na Amazônia Central: fenologia e sucesso no estabelecimento de plantas. Dissertation, Instituto Nacional de Pesquisas da Amazônia - Universidade Federal do Amazonas. (Unpublished). 